\title{
THE RELATION BETWEEN THE BOARD AND THE EXECUTIVE IN CO-OPERATIVES *
}

\author{
by \\ Dr. O.R. KRISHNASWAMI, \\ Prof. and Dean, Faculty of Commerce and Management, \\ Bangalore University, Bangalore
}

\begin{abstract}
INTRODUCTION
Management in a co-operative society has a distinguishing feature. Unlike the management in other forms of enterprise, it has to operate within the framework of democracy. The members of a co-operative society are not mere shareholders but are patrons as well. Their main interest is not in the rate of return on capital contributed by them, but in the quality and cost of the services rendered by the society to them, and accordingly they exercise control over the society as memberpatrons on the basis of 'one man, one vote', and not as mere shareholders. Therefore, their control over the co-operative is deeper and democratic. Accordingly, the management in a co-operative is subject to a complex system of democratic decision-making, which is why it is often found slow and cumbersome. This poses the problem of whether managerial efficiency is compatible with democracy.
\end{abstract}

A desire for more democracy may cause a co-operative board to postpone definite action in some matters until it has consulted the membership. Or the same desire may cause a board to hesitate about giving the executive sufficient authority to go ahead and take expeditious action whenever such action is needed in the interest of the co-operative. On the other hand, if more authority is given to the executive in the interest of prompt action, power may be concentrated in his hands, and democratic control may become ineffective. The question of reconciling efficiency with democratic control is therefore one of establishing a proper relationship between the board and the executive. What should be the role of the board? What powers should it delegate to the executive?

\footnotetext{
* A paper presented in a 3-day seminar for chairmen and managing committee members of consumers co-operative stores in Karnataka, Kerala and Tamilnadu states, organised by the Co-operative Training College, Bangalore in May 1975.
} 
BOARD

The board is the organ of higher control. It is elected by, and collectively responsible to, the members. Why should there be a board? It would be ideal if all the members could directly supervise the management of day-to-day affairs. But even in the case of a small co-operative it would be neither expedient nor economical for the whole membership to try to directly supervise the conduct of affairs. It would also be difficult to arrive at expeditious decisions if the whole body of members had to meet and discuss all matters. Therefore, direct democratic control is not feasible, and the members elect from among themselves directors and confer upon them the authority to control the executive management.

\section{THE NEED FOR MANAGERIAL OFFICIALS}

The board cannot possibly manage a society. It has neither time nor ability to do that, nor is there any need that it should. It appoints a paid executive and other personnel to perform managerial functions. This does not, however, lessen the board's responsibility to members. It should see that the society is managed honestly, efficiently and in the interest of the members.

\section{THE ROLE OF THE BOARD}

The problem of combining democratic control with managerial efficiency is not insoluble, provided the role of the democratically elected board is properly interpreted. As regards the role of the board, there are three alternatives.

The board may act mainly as a members' vigilance committee, or involve itself in executive management or - principally-in policy making. There is a mixture of these functions in the activities of boards, but which should be the primary function?

A board which acts mainly as a vigilance committee will fail to evolve sound policies. A concentration on members' complaints may result in an obsession with matters of detail and the board will find no time to discuss broader issues and formulate sound policies. This cannot, therefore, be considered to be the main role of the board. It will pronıte neither efficiency nor democracy. The former will suffer on account of the chief officials wasting their time on trivial details which should never reach the board room. Democracy will suffer because the elected representatives fail to take responsibility for, and exercise proper control over, major policy decisions. 
A board involved actively in day-to-day management goes to the other extreme. It appoints all personnel down to attendants. It expects the officials to do nothing without consulting it and attempts to share the functions of detailed management with the officials, assuming that only by such participation, can it protect the members' interests.

'The board's interference in detailed management also affects both democracy and efficiency. Firstly, when the board is preoccupied with managerial decisions, sufficient time is not available for considering long-term matters and management is given no guidance on these matters.

Secondly, management decisions will have to wait for board meetings and thus be delayed. The executive is thus unable to take prompt action even on urgent matters.

Thirdly, the work of executives is affected. They have to spend most of their time attending committee meetings, preparing reports and the like, and for want of time cannot adequately fulfil the essential functions of executive management, viz., overall co-ordination, and the preparation of forward plans for the board.

Lastly, too much interference will affect the morale of the officials, it will weaken their sense of responsibility. If they are constantly being watched and deprived of due authority, they will become frustrated and demoralised. Therefore, the board's direct involvement in executive management is also harmful. What then should be its major role?

The major role of the board should be formulation of policies. It should confine itself to the determination of policies, the appointment of competent officials and the supervision of their performance.

\section{POL.ICY-MAKING}

In order to consider the board as a policy-making body, it is necessary to examine the nature of policy. Koontz and O'Donnel have described policy as 'general statements or understandings which guide or channel the thinking in decision-making of subordinates'. ${ }^{1}$ This definition indicates that the making of policy refers to broad guidelines or principles subject to which, or to the framework within which, the executives should act in carrying out the objective of the organisation. It provides for consistency of action in the making of decisions in similar situations. The objective sets the goal, and the policy shows the way leading towards the goal. Policy indicates to management what the policy makers intend to achieve and the extent to which the goal is 
expected to be achieved. It provides management with a basis for its own attitude and behaviour and for the day-to-day decisions which it has to make. For example, the objective of a consumers' co-operative store is to supply pure and unadulterated goods to its members at reasonable prices. The guidelines relating to purchase of goods such as the assortment of goods to be procured; the producers or wholesalers from whom they are to be procured; the selling margin to be added to the cost price; whether to produce an item of goods or to procure it from the producers or traders, etc. - all these are policies. These policies govern day-to-day management, i.e. the placing of orders, fixing of prices, etc.

\section{TYPES OF POLICIES}

Policies cover various operations of an enterprise such as business, finance, investment and personnel.

Policies may be classified in two groups: basic and general. A basic policy is a statement of the long-term principles which guide the executive management. It sets a long-range course and provides management with directions for achieving goals. In a consumers' co-operative, it may, for instance, cover the following matters: whether to specialise in groceries only or deal in all kinds of consumer goods; whether or not to go in for production of such goods as oil, flour, rava, soap-nut powder, etc.; whether to allow discount on sales to members or to pay them bonuses out of profits on a pro rata basis; whether to raise additional capital from membership or to raise loans from banks: whether or not to construct its own buildings and so on.

A general policy refers to the operational guidelines. It is less universal in its application. It may be modified from time to time. It may cover such aspects as rates of interest payable on different types of deposits, credit limits, pricing policy, inventory levels, etc.

\section{DEVELOPING POLICIES}

The board must assume full responsibility for developing policies and evaluating the results obtained from their operation. But it may be asked whether lay board members are capable of formulating longrange major policies. It is true that policy making is too complicated for a lay board. But the board does not act in isolation. It is provided with information, expert advice, and suggestions by the chief executive. This is important as the policies become more directly involved with the details of operation. In view of this fact, the relationship of the chief executive to the board is crucial. Any struggle between them for dominance will have far-reaching consequences. If the board is able to dominate, efficiency may suffer, and if the chief executive is 
able to dominate, the democratic control will become weaker. Therefore, cordial and good relations should exist between the board and the chief executive. How the chief executive should conduct himself has been described beautifully by K.C. Wheare: 'An official must at times be a committee's nurse, at times its tutor, at times its conscience, at times its candid friend - yet always its servant, never its master'. ${ }^{2}$

\section{DIVISION OF FUNCTIONS BETWEEN THE BOARD AND THE CHIEF EXECUTIVE}

A sound and open relationship between the co-operative board and the chief executive is essential to the success of a co-operative organisation. This relationship should be based on a proper division of functions between the board and the executive. As already explained, the board should concentrate on deciding major policies and leave management to the chief executive, giving him necessary authority, but not interfering in day-to-day management. This is the solution for solving the problem of combining efficiency with democracy. It is difficult to clearly demarcate the policy-making function from managerial function. However, a broad division of functions can be made.

\section{FUNCTION OF THE BOARD}

The following may be regarded as the proper functions of the board.

1. The board should ascertain the needs and preferences of members and shape the society's business pattern according to these needs and preferences.

2. The board should assume responsibility for all operations. The board, as an elected representative body, is accountable to the members for the success or failure of operations.

3. The board as trustee for the members should safeguard and manage the assets of the co-operative in the interest of all members and on their behalf.

4. The board should interpret the objectives of the society to the executive management.

5. It should lay down the major policies to ensure the achievement of the society's objectives, set down goals to be achieved and change the operational policies from time to time in the light of changing situations. The policies should cover the main business, finance, personnel and investment. The policies should be made on sound

2 K.C. Wheare: Government by Committee, Oxford, Clarendon Press, 1955, p. 204. 
lines, based on study and analysis of the available facts and reflect the will of membership.

6. The board should select competent chief officials and determine their salaries and terms of service. This is a vital function, guaranteeing democratic control. The efficiency of the society depends on how judiciously this power is exercised. The board, however, should not appoint officials below the top level, but only lay down the policy and budget for the purpose and allow the executives to make the actual selection of the subordinate personnel.

7. The board should delegate responsibility and authority to the chief executive. Each assignment of responsibility requires a corresponding delegation of authority.

8. The board should approve budgets, receive reports, accounts and operational statements from the executive, scrutinise them carefully, to make sure that plans of action have been carried out as intended, and appraise the working and progress of the society in achieving the set goals.

9. The board should take steps to keep the members fully informed of the society's activities and problems.

\section{FUNCTIONS OF THE EXECUTIVE}

The executive is responsible for the details of management. His job covers two broad fields: management of business operations, and management of men. Both are important to the co-operative, and its measure of success depends upon the efficient performance of these functions. The major tasks of the executive are:

1. To remember that he is an employee, deriving his authority from the board and therefore, respect the board as his employer.

2. To formulate the business operations required to achieve the objectives of the socjety.

3. To set operational goals, make plans and take steps to carry out the general policies laid down by the board.

4. To furnish the board with the information required for formulating policies and for long-range planning.

5. To select appropriate personnel to discharge the various duties of management subject to the personnel policies and budget laid down by the board.

6. To plan the internal organisation of the society, developing a logical structure as a framework for performing functions of the 
co-operative and assign appropriate duties of the employees with delegation of appropriate authority to them.

7. To supervise and co-ordinate the various activities of the co-operative and see that every one works harmoniously towards the goals of the co-operative in accordance with the general policy laid down by the board.

8. To employ methods of control in order to see if his plans are working satisfactorily, to check results and to make improvements.

9. To report to the board periodically on the working of the society and furnish the board with the information needed for appraising the operation of the society.

10. To assume responsibility for operations as delegated by the board.

In the Indian co-operatives, the respective functions of the board and the chief officials have been clearly laid down in their by-laws. But the pattern of division of functions clearly involves placing managerial responsibilities primarily on the board or the executive committee and the president. The secretary who is the chief executive is not the effective administrative head; usually it is the president who performs this function. This pattern is not conducive to efficient management. Every co-operative should leave the managerial responsibilities to the paid executive and the board should concentrate on policy-making, long-range planning and evaluation of executive management.

A close study of the top government in co-operatives is necessary to determine the lines on which the top government could be reorganised for achieving the ideal of efficiency with democracy. 